\section{Acetolactate Synthase Inhibitors Increase Ethylene Production and Cause Fruit Drop in Citrus}

\author{
Jacqueline K. Burns ${ }^{1}$, Ulrich Hartmond ${ }^{2}$, and Walter J. Kender ${ }^{3}$ \\ University of Florida, Institute of Food and Agricultural Sciences, Citrus \\ Research and Education Center, 700 Experiment Station Road, Lake Alfred, \\ FL 33850-2299
}

Additional index words. abscission, herbicides, growth regulators, imazameth, imidazolinone, metsulfuron-methyl, pH effect, prosulfuron, sulfonylurea, temperature effect, Citrus sinensis,

Citrus paradisi

Abstract. The abscission action of two sulfonylureas and one imidazolinone was evaluated in laboratory studies with harvested orange (Citrus sinensis L. cv. Valencia) fruit and greenhouse studies with orange (cv. Hamlin) and grapefruit (Citrus paradisi Macf. cv. Marsh) trees. Dipping harvested fruit in $90 \mathrm{mg} \cdot \mathrm{L}^{-1}$ imazameth, $2 \mathrm{mg} \cdot \mathrm{L}^{-1}$ metsulfuronmethyl, or $30 \mathrm{mg} \cdot \mathbf{L}^{-1}$ prosulfuron solutions increased levels of internal ethylene. Internal ethylene concentration was higher when fruit were dipped in $2 \mathrm{mg} \cdot \mathrm{L}^{-1}$ metsulfuron-methyl solutions at low $\mathrm{pH}$. Fruit retained on trees and dipped in $2 \mathrm{mg} \cdot \mathrm{L}^{-1}$ metsulfuron-methyl solutions produced more ethylene than control fruit. Drop of treated fruit began when ethylene production was at a maximum. High temperatures (average $33{ }^{\circ} \mathrm{C}$ ) suppressed ethylene production and fruit drop of metsulfuron-methyl-treated fruit. The results indicate the importance of environmental conditions in evaluating the potential of sulfonylureas and imidazolinones as abscission agents for citrus. Chemical names used: \pm 2-[4,5-dihydro-4-methyl-4-(1-methylethyl)-5-oxo-1H-imidazol-2-yl]-5-methyl-3pyridinecarboxylic acid (imazameth); methyl 2-[[[[(4-methoxy-6-methyl-1,3,5-triazin2yl) amino] carbonyl] amino] sulfonyl] benzoate (metsulfuron-methyl); 1-(4-methoxy-6methyl-triazin-2-yl)-3-[2-(3,3,3-trifluoropropyl) phenylsulfonyl] urea (prosulfuron); $\mathrm{N}$ (phosphonomethyl) glycine (glyphosate); 2-[4,5-dihydro-4-methyl-4-(1-methylethyl)-5oxo-1 $H$-imidazol-2-yl]-3-quinolinecarboxylic acid (imazaquin).

Sulfonylurea and imidazolinone herbicides are widely used to control broadleaf weeds in agronomic crops. These herbicides inhibit acetolactate synthase (ALS), an enzyme involved in the biosynthesis of branched chain amino acids (LaRossa and Schloss, 1984). In addition to their activity as herbicides, sulfonylureas and imidazolinones promote abscission in citrus (Wilcox and Taylor, 1996, 1997). When sprayed on fruiting branches, some compounds induced fruit drop of mature oranges but did not affect leaves. In general, rates of application for citrus fruit abscission were at least an order of magnitude lower than those recommended for herbicidal activity. Many sulfonylurea and imidazolinone compounds are known, and their herbicidal activities differ with various substitutions made on each toxophore (Hay, 1990; Ladner, 1990). Thus, abscission activity could differ as well. The purpose of this study was to test the abscission activity of these compounds and

Received for publication 26 Oct. 1998. Accepted for publication 28 Jan. 1999. Florida Agricultural Experiment Station Journal Series No. R-06580. The cost of publishing this paper was defrayed in part by the payment of page charges. Under postal regulations, this paper therefore must be hereby marked advertisement solely to indicate this fact.

${ }^{1}$ Associate Professor; to whom reprint requests should be addressed. jkbu@lal.ufl.edu

${ }^{2}$ Biological Scientist.

${ }^{3}$ Professor. identify conditions that affect response. We applied commercial formulations of two sulfonylureas, metsulfuron-methyl and prosulfuron, and one imidazolinone, imazameth, to either harvested fruit or fruit maintained on greenhouse-grown trees, and measured fruit ethylene production and fruit drop. Ethylene production is highly correlated with abscission in plant organs (Brown, 1997). We, therefore, used ethylene accumulation or production in fruit as a basis for evaluating the abscission potential of these compounds.

\section{Materials and Methods}

Studies with harvested fruit. Mature fruit from field-grown 'Valencia' trees at the Citrus Research and Education Center, Lake Alfred, Fla., were harvested by clipping the peduncle $1 \mathrm{~cm}$ above the fruit calyx. Fruit (20 fruit/ treatment) were dipped to the peduncle in 90 $\mathrm{mg} \cdot \mathrm{L}^{-1}$ a.i. imazameth ('Cadre'; American Cyanamid, Parsippany, N.J.); $2 \mathrm{mg} \cdot \mathrm{L}^{-1}$ a.i. metsulfuron-methyl('Ally'; DuPont Chemical Co., Wilmington, Del.); or $30 \mathrm{mg} \cdot \mathrm{L}^{-1}$ a.i. prosulfuron ('Peak'; Novartis, Basel, Switzerland) solutions for $10 \mathrm{~s}$. The dipping solution also contained an organosilicone adjuvant $(0.125 \%$ Kinetic; Setre Chemical Co., Memphis, Tenn.) and a buffer $(0.02 \%$ Buffer Xtra Strength; Setre Chemical Co.) to adjust the $\mathrm{pH}$ to 6.5. Control fruit were dipped in solutions containing adjuvant and buffer only. To determine the effect of solution $\mathrm{pH}$ on internal ethylene accumulation, fruit (20 fruit/ treatment/time period) were dipped in solutions of metsulfuron-methyl $\left(2 \mathrm{mg} \cdot \mathrm{L}^{-1}\right.$ a.i. $)$ containing adjuvant and either $100 \mathrm{~mm}$ citrate, 2-( $N$-morpholino) ethanesulfonic acid (MES; Sigma, St. Louis) or 3-(N-morpholino) propanesulfonic acid (MOPS; Sigma) adjusted to $\mathrm{pH} 4.5,5.5$ (citrate), 6.5 (MES), or 7.5 (MOPS) with $\mathrm{HCl}$ or $\mathrm{NaOH}$. Control fruit were dipped in buffered solutions containing adjuvant without metsulfuron-methyl. Fruit were placed in a storage room held at $24^{\circ} \mathrm{C}$ and $92 \%$ relative humidity $(\mathrm{RH})$. At various times up to $10 \mathrm{~d}$ after dipping, internal ethylene accumulation was measured by sampling the evacuated fruit airspace. Fruit were submerged in water and vacuum applied $(60 \mathrm{~mm} \mathrm{Hg})$ for $10 \mathrm{~s}$. Evacuated fruit airspaces were collected in the neck of an inverted funnel placed over the fruit. For ethylene determinations, $1 \mathrm{~mL}$ headspace was injected into a gas chromatograph. Studies with harvested fruit were repeated twice. Internal ethylene concentrations are presented as the means of 40 fruit replicates with standard error of the mean.

Greenhouse studies. To determine the effect of temperature on activity of metsulfuronmethyl, a set of six potted trees each of 'Hamlin' orange and 'Marsh' grapefruit, 6 to 8 years of age, were placed in greenhouses held at average temperatures and humidities of either 33.3 $\pm 1.7{ }^{\circ} \mathrm{C}$ and $47.2 \% \pm 5.2 \% \mathrm{RH}$, or $17.7 \pm 1.4$ ${ }^{\circ} \mathrm{C}$ and $82.1 \% \pm 7.5 \%$ RH. Trees were held at these temperatures for $24 \mathrm{~h}$ before treatments were applied. While attached to the tree, 16 mature fruit were dipped to the peduncle in a solution of $2 \mathrm{mg} \cdot \mathrm{L}^{-1}$ a.i. metsulfuron-methyl, $0.125 \%$ Kinetic and $0.02 \%$ Buffer Xtra Strength adjusted to $\mathrm{pH} 6.5$, and 16 control fruit were dipped in a solution containing only adjuvant and buffer. Each fruit was then enclosed in a 0.7-L (orange) or 1.5-L (grapefruit) Rubbermaid plastic container and maintained on the tree. The peduncle was carefully slipped through a slit down the side of the container and placed in a hole $5 \mathrm{~mm}$ in diameter punched at the end of the slit. The open spaces between the peduncle and the container were sealed with nonphytotoxic 3140 Mil-A-46146 RTV coating (Dow Corning, Midland, Mich.). At 0, $2,5,7$, and $10 \mathrm{~d}$ after dipping, the containers with fruit inside were closed with the plastic lid and sealed with Parafilm (American National Can, Chicago). After $1 \mathrm{~h}$, a headspace gas sample was withdrawn from the sealed container through the rubber septum affixed to the lid, and ethylene concentration was measured by gas chromatography as previously described (Kazokas and Burns, 1998). Dropped fruit remained in the containers and were counted at each ethylene sampling period. Ethylene production was determined in abscised fruit in the containers or in attached fruit. Cumulative percentage of fruit drop was determined by dividing the sum of the dropped fruit by the total number of containerized fruit. Fruit ethylene production and percent cumulative fruit drop are presented as the means of 16 determinations with standard error of the mean. 


\section{Results and Discussion}

Studies with harvested fruit. Dipping harvested fruit in solutions of either imazameth, metsulfuron-methyl, or prosulfuron increased internal ethylene concentration (Fig. 1), making these chemicals potential candidates for abscission agents. Significant increases in internal ethylene production occurred $2 \mathrm{~d}$ after dipping fruit in imazameth or prosulfuron and $3 \mathrm{~d}$ after dipping fruit in metsulfuron-methyl. Dipping harvested fruit in metsulfuron-methyl solutions at $\mathrm{pH} 4.5$ caused the largest increase in internal ethylene production $6 \mathrm{~d}$ after application (Fig. 2). High ethylene production levels were also induced (sustained) in fruit treated with metsulfuron $\mathrm{pH}$ 4.5. In contrast, treatment with metsulfuron-methyl solutions between $\mathrm{pH} 5.5$ and 7.5 was less effective, and internal ethylene concentrations declined after $10 \mathrm{~d}$. Reducing the $\mathrm{pH}$ of solutions containing sulfonylureas or imidazolinones increases compound lipophilicity, promoting greater uptake across cellular membranes (Hay, 1990). However, hydrolysis of sulfonylurea increases as $\mathrm{pH}$ is reduced, limiting the use of low $\mathrm{pH}$ to increase uptake.

Greenhouse studies. Metsulfuron-methyl increased ethylene production in fruit of trees held in the $18^{\circ} \mathrm{C}$ greenhouse between 2 and 5 $\mathrm{d}$ after treatment. Fruit drop of both 'Hamlin' orange and 'Marsh' grapefruit began as ethylene production peaked (Fig. 3). Total fruit drop was $72 \%$ and $56 \%$ after $10 \mathrm{~d}$ in oranges and grapefruit, respectively. In contrast, an average greenhouse temperature of $33{ }^{\circ} \mathrm{C}$ markedly reduced ethylene production and fruit drop of mature orange and grapefruit treated with metsulfuron-methyl. Fruit ethylene production was low and did not significantly change during the course of the study, and cumulative fruit drop was $<7 \%$ in both species. High temperatures reportedly reduce herbicidal activity of sulfonylurea and imidazolinone herbicides severely because of the rapid rate of detoxification in treated tissues (Hay, 1990; Ladner, 1990). Temperatures $>30^{\circ} \mathrm{C}$ also reduce ethylene production (Abeles et al., 1992). Temperatures $>33^{\circ} \mathrm{C}$ can occur during the citrus harvesting season that typically begins in October and ends in May. Application of sulfonylureas or imidazolinones to stimulate fruit abscission should be avoided during periods of high temperature.

Application of sulfonylureas or imidazolinones to citrus caused ethylene production and fruit drop, but the reason for increased ethylene production after application remains unclear. Treatment of bean (Phaseolus vulgaris L.) seedlings with glyphosate increased ethylene and $\mathrm{CO}_{2}$ production, suggesting that chemical wounding had a role in the response (Abu-Irmaileh et al., 1979). Chemical wounding of peel in response to abscission materials was considered to be the cause of ethylene production in whole citrus fruit (Evensen et al., 1976; Holm and Wilson, 1977), and ethylene may originate from wound-specific up-regulated ethylene

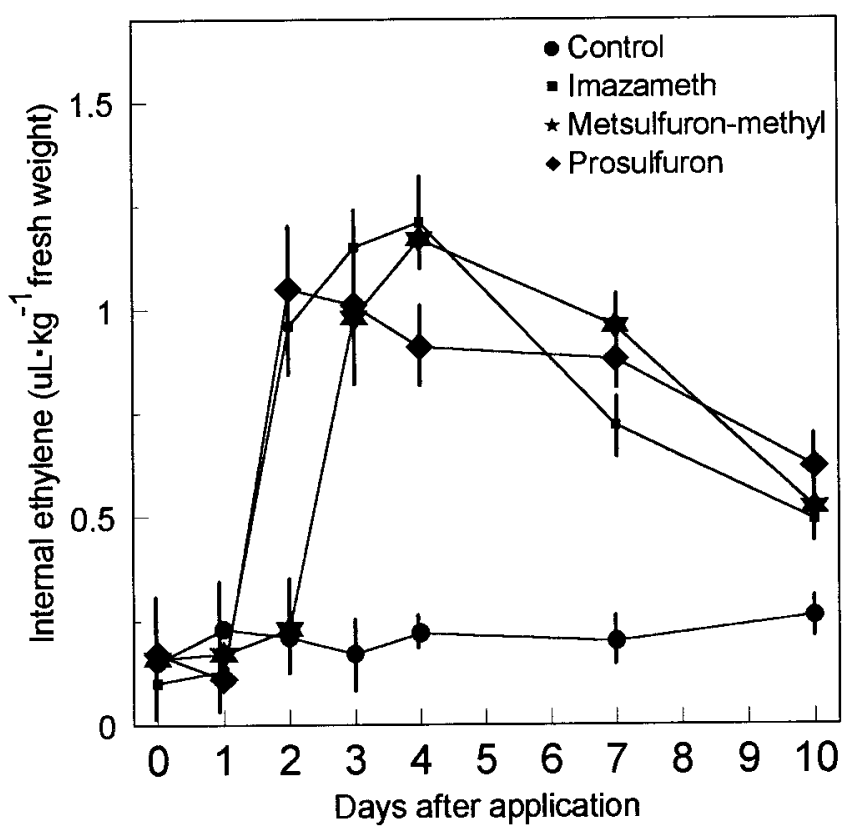

Fig. 1. Effects on internal ethylene concentration of dipping harvested 'Valencia' orange fruit in solutions of imazameth $\left(90 \mathrm{mg} \cdot \mathrm{L}^{-1}\right)$, metsulfuron-methyl $\left(2 \mathrm{mg} \cdot \mathrm{L}^{-1}\right)$, or prosulfuron $\left(30 \mathrm{mg} \cdot \mathrm{L}^{-1}\right)$ containing $0.125 \%$ Kinetic and $0.02 \%$ Buffer Xtra Strength. Control fruit were dipped in Kinetic and Buffer Xtra Strength alone. Vertical lines through points indicate SE.

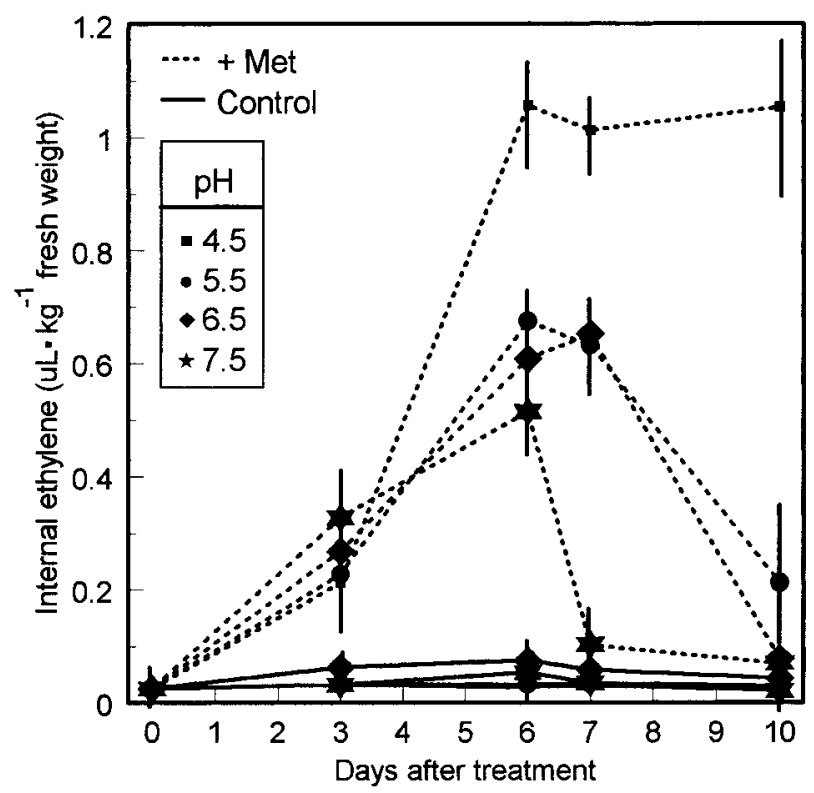

Fig. 2. The effect of solution $\mathrm{pH}$ on internal ethylene concentration of harvested 'Valencia' orange fruit treated with metsulfuron-methyl (Met) $\left(2 \mathrm{mg} \cdot \mathrm{L}^{-1}\right)$. Vertical lines through points indicate SE.

biosynthetic genes (Morgan and Drew, 1997). However, Risley (1986) showed that imazaquin reduced wound ethylene production in leaf discs. Metsulfuron-methyl $\left(2 \mathrm{mg} \cdot \mathrm{L}^{-1}\right)$ also reduced ethylene production in discs $(1 \mathrm{~cm}$ diameter $\times 4 \mathrm{~mm}$ thick) of orange peel (Burns, Hartmond, and Kender, unpublished), indicating that wounded tissue responds differently than do whole fruit. In whole fruit or tissues treated with acetolactate synthase inhibitors, increased ethylene production may not be a direct consequence of wounding. Amino acid metabolism can be greatly altered as a consequence of acetolactate synthase inhibition. Transgenic potato plants with repressed ALS activity have reduced levels of valine and leucine, but greatly elevated levels of several other amino acids, including a 5-fold increase in methionine (Höfgen et al., 1995). Methionine originating from this source may boost the normally low endogenous pool of methionine (Abeles et al., 1992) and be utilized by the plant to synthesize ethylene coincident with the abscission process.

We have confirmed that sulfonylurea and imidazolinone compounds show potential as abscission materials for citrus. Although these compounds caused variable peel pitting in whole fruit, there were no detrimental effects on internal quality (data not shown), indicat- 


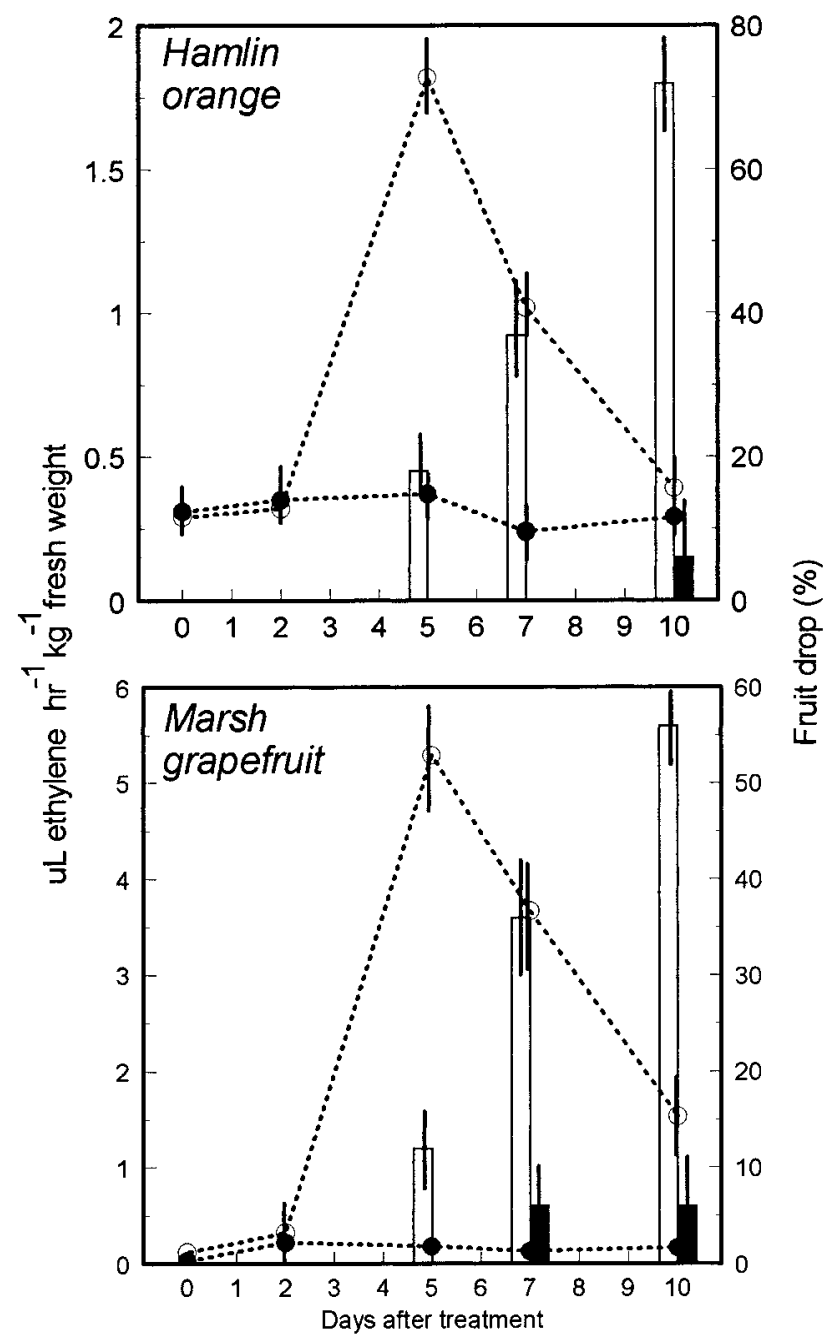

Fig. 3. Fruit ethylene production and percent cumulative fruit drop in 'Hamlin' orange and 'Marsh' grapefruit trees held in greenhouses at average temperatures of $18^{\circ} \mathrm{C}(\bigcirc)$ or $33^{\circ} \mathrm{C}(\bullet)$. Fruit were dipped in metsulfuron-methyl $\left(2 \mathrm{mg} \cdot \mathrm{L}^{-1}\right)$ and maintained on the tree. Open bars indicate percent cumulative fruit drop at $18{ }^{\circ} \mathrm{C}$, and solid bars indicate fruit drop at $33^{\circ} \mathrm{C}$. Vertical lines through points indicate sE. Control fruit ethylene production (not shown) at both temperatures remained below $0.25 \mu \mathrm{L} \cdot \mathrm{h}^{-1} \cdot \mathrm{kg}^{-1}$ fresh weight throughout the duration of the study.

ing that the greatest potential for these classes of compounds exists for fruit destined for the processing market. Whether these compounds can be successfully adapted into citrus management and production practices remains to be determined. To be fully embraced by the
Florida citrus industry, an abscission material must: 1) be selective for mature fruit;2) loosen fruit uniformly; 3) not affect subsequent yield; 4) not be phytotoxic; and 5) have a high probability of registration (Kender, 1998). We are currently evaluating these abscission agents at various application rates for their ability to loosen Florida citrus under commercial conditions.

\section{Literature Cited}

Abeles, F.B., P.W. Morgan, and M.E. Saltveit, Jr. 1992. Ethylene in plant biology. 2nd ed. Academic Press, San Diego.

Abu-Irmaileh, B.E., L.S. Jordon, and J. Kumamoto. 1979. Enhancement of $\mathrm{CO}_{2}$ and ethylene production and cellulase activity by glyphosate in Phaseolus vulgaris. Weed Sci. 27:103-106.

Brown, K.M. 1997.Ethylene and abscission. Physiol. Plant. 100:567-576.

Evensen, K.B., M.G. Bausher, and R.H. Biggs. 1982. Temperature effects on uptake and effectiveness of glyoxal dioxime in 'Hamlin' oranges. HortScience 17:675-676.

Hay, J.V. 1990. Chemistry of the sulfonylurea herbicides. Pestic. Sci. 29:247-261.

Höfgen, R., B. Laber, I. Schüttke, A. Klonus, W. Streber, and S. Pohlenz. 1995. Repression of acetolactate synthase activity through antisense inhibition. Plant Physiol. 107:469-477.

Holm, R.E. and W.C. Wilson. 1977. Ethylene and fruit loosening from combinations of citrus abscission chemicals. J. Amer. Soc. Hort. Sci. 102:576-579.

Kazokas, W.C. and J.K. Burns. 1998. Cellulase activity and gene expression in citrus fruit abscission zones during and after ethylene treatment. J. Amer. Soc. Hort. Sci. 123:781-786.

Kender, W.J. 1998. The Florida experience with abscission materials, p. 52-56. In: J.K. Burns and W.J. Kender (eds.). Citrus Abscission Wkshp., Lake Alfred, Fla.

Ladner, D.W. 1990. Structure-activity relationships among the imidazolinone herbicides. Pestic. Sci. 29:317-333.

LaRossa, R.A. and J.V. Schloss. 1984. The sulfonylurea herbicide sulfometuron is an extremely potent and selective inhibitor of acetolactate synthase in Salmonella typhimurium. J. Biol. Chem. 259:8753-8757.

Morgan, P.W. and M.C. Drew. 1997. Ethylene and plant responses to stress. Physiol. Plant. 100:620 630.

Risley, M.A. 1986. Imazaquin herbicidal activity: Efficacy, absorption, translocation and ethylene synthesis. PhD Diss., Dept. of Agronomy, Univ. of Arkansas, Fayetteville.

Wilcox, M. and J.B. Taylor. 1996. TRANSFER: A new abscission agent, p. 1013-1016. In: Proc. Intl. Soc. Citricult.

Wilcox, M. and J.B. Taylor. 1997. Citrus abscission at very low application rates. Proc. Interamer. Soc. Trop. Hort. 41:145-151. 